\title{
The Prospects of Ethnography at the Sámi School
}

\author{
Pigga Keskitalo \\ Sámi University College, Kautokeino, Norway \\ Ounastie 3039, 99420 Peltovuoma, Finland
}

Tel: 358-40-419-7175 E-mail: pigga.keskitalo@samiskhs.no

Kaarina Määttä (Corresponding author)

Faculty of Education, University of Lapland

P. O. Box 122, 96101 Rovaniemi, Finland

Tel: 358-400-696-480Ｅ-mail: Kaarina.Maatta@ulapland.fi

\author{
Satu Uusiautti \\ Faculty of Education, University of Lapland \\ (May-Sep) Lepolantie 29, 01830 Lepsämä / (Oct-Apr) 2403 SE 8th Avenue \\ Cape Coral 33990, FL, USA
}

Tel: 358-50-355-1280 / 1-239-789-5562Ｅ-mail: satu@uusiautti.fi

$\begin{array}{lc}\text { Received: August } 29 & \text { Accepted: September } 16 \quad \text { Published: December 1, } 2011 \\ \text { doi:10.5296/jse.v1i1.911 } & \text { URL: http://dx.doi.org/10.5296/jse.v1i1.911 }\end{array}$

\begin{abstract}
Ethnographic research has become a salient qualitative research method for studying the phenomena of education and schooling and when the aim is to reach the authentic reality. But how applicable is this method to indigenous peoples' research, such as the Sámi? What is the ethnographer's role at the Sámi School? The purpose of this article is to 1) contemplate the ethnographic research approach in school research, 2) review its applicability to studying Sámi education by using one ethnographic research process as an example, and 3) to create a picture of the Sámi School with the ethnographic research. Ethnography seems to suit well indigenous studies if the aim is to genuinely understand the target, like the Sámi School in the sample research, together with the research partners and from their point of view - especially, if the researcher is also a bearer of the Sámi culture.
\end{abstract}


Keywords: Indigenous people, School ethnography, The Sámi, Sámi education, Research ethics 


\section{Introduction}

Educational research has become more and more versatile and traveled a long road from quantitative research toward various qualitative methods (Creswell, 2003; Henson et al., 2010). Ethnography has been recognized as a suitable method when the aim is to understand people and their life in the context they live (Hostetler, 2005). Given this starting point, ethnography is well applicable when doing research on indigenous peoples' cultures, education, and life. Institutions like school have come to serve as mediators between indigenous communities and the outside world, and they are sites in which scholars can contribute to community-based research without intruding on private life. Simultaneously, such institutions are ideal for the study of processes of, for example, self-representation, self-determination, repatriation, and economic development. (Turner Strong, 2005.)

In this article, we review the typical features of ethnographic research and its applicability to the studying of Sámi education. Our analysis is based on the first author's dissertation "Cultural Sensitivity in The Sámi School Through Educational Anthropology" (Keskitalo, 2010). She is a Sámi teacher herself who studied the classroom culture at the Norwegian Sámi School, its teaching arrangements and special linguistic and cultural characteristics. We will introduce the special features of this research process and pursue presenting a new viewpoint to research on Sámi education which is one part of our current research project launched at the University of Lapland (see http://lbleadership.wordpress.com) and directed by Professor Kaarina Määttä.

The Sámi live in four countries: in Finland, Sweden, Norway, and Kola Peninsula in Russia. Altogether, there are about 100000 Sámi people in these countries. About 40000 of them can speak the Sámi language. The word 'Sámi' is derived from the word in Sámi language 'Sápmi' which means the geographical area populated traditionally by the Sámi. The Sámi people form a nationality that does not have a nation or nation borders but a common language, culture, and history (Smith, C., 2005). It should be noted that Sámi can be written in the English language as Sami, Sámi, or Saami but we use the word Sámi. The definition of Sámi varies by country. According to the one used in Norway is based on the Sami electoral register:

"All persons who make a declaration to the effect that they consider themselves to be Sami, and who either a. have Sami as their domestic language, or b. have or have had a parent, grandparent or great-grandparent with Sami as his or her domestic language, or c. are the child of a person who is or has been registered in the Sami electoral register may demand to be included in a separate register of Sami electors in their municipality of residence. The Sami electoral register is drawn up on the basis of the national population register in the municipality, the register of Sami electors at the time of the last election and the demands for inclusion or deletion received during the electoral term." (Act of 12 June 1987 No. 56, § 2-6.)

The Sámi are recognized as one of the indigenous peoples. There are several definitions for indigenous people but in this research, we use the definition compiled by the International Labour Organization (ILO no. 169, 1989). Among the countries with Sámi population, only 
Norway has ratified the ILO 169 convention in 1990 (see Utdanningsdirektoratet, 2007). The definition of indigenous people in ILO 169 convention grounds on the assumption that the nation is governed by some other population than the indigenous one. In addition, the indigenous population in question has to identify itself as indigenous people. The Sámi have their own culture, language, and means of livelihood as well as a distinct connection with the traditional territories and territorial waters. (Henriksen et al., 2005.) The debate concerning indigenous people has raised the Sámi at a new position (see Valkonen, 2009).

In the 1970s, Anton Hoëm (1978) introduced a model of the socialization process of education. The Sámi started to write by themselves more and more about educational issues in the 1990s. Previous research that relate to the science of education has been focused on the Sámi school history and on political research. Recently, more attention has been paid on how the western education has affected individuals, local culture, and knowledge. For example, Asta Balto $(1997 ; 2008)$ has studied the phenomenon of traditional Sámi upbringing and adapted the results to the practices of Sámi comprehensive education.

Along research, the forms of indigenous knowledge are beginning to be understood by scholars (Murillo, 2009) - even to the extent where methods of collecting, analyzing and presenting data characterize the western academic tradition as well as indigenous ways of knowing, communicating and sharing knowledge (Webster \& John, 2010). Indeed, when the purpose is to rethink schooling from the perspective of indigenous peoples' own needs, it is worth asking how educational practices and curriculum will need to change to recognize and incorporate local forms of knowledge and ways of knowing.

This article is connected to the research on Sámi education that was originally launched by the Sámi University College in Norway and the University of Lapland in Finland. Next, we will introduce ethnography as a method briefly and then focus on special issues about researching indigenous people and their education as an ethnographer.

\section{What is Ethnography?}

Ethnography as a word is derived from a Greek word 'ethnos' which refers to a tribe or people and a word 'graphia' which means 'to write' (Opas, 2004). Thus, ethnography aims to describe the nature of those who are studied (i.e. to describe a people, an ethnos) through writing. The roots of ethnography are in anthropology (Metsämuuronen, 2006) - and often among quite exotic and remote research targets. Polish Bronislaw Malinowski conducted research among the habitants of the island of Trobriant between 1913 and 1916 and made the concept of "field" in ethnographic research well-known (Malinowski, 1984).

Ethnography can be defined in many ways (Lappalainen, 2006). According to Clifford Geertz (1973), ethnography is thick description about culture (see also James, 2001); whereas Beverley Skeggs (1999) defines it as a way of seeing otherwise. Paul Atkinson and Martin Hammersley (1994) compare it with an expedition during which the researcher works with unstructured material and is interested in the research target.

Usually, working in the field and writing as well as the purpose to understand and describe the research target analytically through observation are part of ethnography. Traditionally, an 
ethnographer is seen as a lonely hero, a maverick, who in defiant of dangers goes in the field, returns and tells the world about his/her exciting experiences (Gerstl-Pepin \& Gunzenhauser, 2002). A castaway's role is an ethnographer's dream because then it is not necessary to pay for keep and, at its best, the researcher becomes a member of the community almost by itself (Eräsaari, 1994). Hawaiian Haunani Kay Trask (1993) calls anthropologists teachers who exploit indigenous peoples' hospitality and generosity. Anishinaabe Author and Professor Gerald Vizenor (1999) has made an ironic statement that you can never criticize anthropologists too much (see also Kuokkanen, 2002). Vizenor calls them academic pretadors who pose with their prey in photos (Vizenor, 1999). However, the major challenge is getting access to the field as western researchers through history have met serious problems when trying to collect data in cultures different from their own. It condenses the core of ethnography that grounds on anthropology as this kind of approach can be seen problematic from indigenous peoples' point of view. The new school disassociates itself from the anthropologic tradition when it comes to research on education and schooling (see also Geertz, 1973, 2010; Ogbu, 1982; Smith, L.T, 2005) and aims at highlighting issues related to power relationships and epistemology. Our research aims at theoretizing and noticing the culture through its own premises (see Geertz, 1973; 2010).

Ethnography is a sort of umbrella that covers various methodological approaches. It has been used in many disciplines. It has also been named directly by the context where the research is conducted: virtual ethnography (Anttonen 2004), ethnography of experience (Rantala 2005), hospital ethnography (Van der Geest \& Finkler, 2004), autobiographical auto-ethnography (Atkinson, 2004), and school ethnography which has been implemented already for over three decades (Gordon et al., 2001). However, research at school differs from traditional anthropologist research because school is not totally strange or unfamiliar. Everyone has some kinds of school experiences. Often, familiarity is considered problematic to the reliability of the research (Coffey, 1999). An ethnographer who conducts research at school has to be able to re-consider what is already known and safe (Gordon et al., 2000).

In ethnographic writing, information is produced through a dialogue between the intrinsic and extrinsic, the old and new, and experience. Field work may represent an existentialistic experience and situation where the researcher's identity is formed when the researcher confronts otherness which is often quite problematic. This dialogue is one of the methods in ethnography. (Moltu, 2004.)

\section{School Ethnography among Indigenous Peoples}

Western imperialism created considerable trouble and insecurity to indigenous peoples around the world. Compromises, coalitions, and power centralization strongly affect educational policy, the science of education, and society and culture otherwise too. (Singh et al., 2005.) Issues concerning indigenous peoples' education are closely connected to the concepts of power and democracy and human rights (King \& Schielmann, 2004). For example, Juha Suoranta (1999) points out that often the problems are seen from the western point of view not being able to recognize their true nature. Therefore, the criticism toward colonialism has given birth to the idea of anthropologist action and participatory research 
with educational issues at the center.

When it comes to the Sámi, previously anthropologists wandered in Lapland researching initiated by outsiders (the most active lappologists were, for example, Nickul, T. I. Itkonen, J. K. Qvigstad, and K. B. Wiklund). It is worthwhile to notice the lappological tradition as a factor that affects Sámi research. Lappology is the antecedent of Sámi research and research on the Sámi people - however, the lappological research was conducted by outsiders in order to build the identities of the Norwegians, Finns, and Swedes simultaneously creating a picture of the Sámi as the opposite and other without any possibilities to survive in the modern world. It has described the Sámi culture from the outsider's point of view from the end of the 17th century till the end of the 20th century - this period was colored by colonialism, imperialism, nationalism, social Darwinism, and cultural racism. (Schanche, 2002.) Veli-Pekka Lehtola deliberated the connection between Sámi research and lappology is viewed in the following manner: All modern researchers are followers of the lappological tradition. The lappologists' role at their own time was not that black and white as is claimed. By deciphering the lappologists' real role in their own community, it is possible to study the present roles: the relationships between the researcher, scientific community, and society. (cited in Vilkuna, 2005, p. 258.) During the past decades, Sámi research has moved toward intercultural approach: the intent has been to replace the term 'lappology' with a new appellation 'multidisciplinary Sámi research' that also the Sámi participate in (The encyclopaedia of Sámi culture, 2003).

The macro-level problems of Sámi research relate to the colonization of the Sámi and affect directly to the micro-level. The features that are typical of school research effect in the background. For example, the personnel do not necessarily trust that the research would improve the everyday situation at school. It can be called research skepticism which also bears the burden of lappology. Yet, it is worth remembering that a teaching situation is - or at least should be - open by nature and that openness is the key word when aiming at developing school (Kohonen \& Leppilampi, 1992).

The same phenomenon of skepticism has been noticed in other communities as well. Indigenous people are generally cynical about the benefits of research and cautious toward what many perceive to be the colonial mentality or 'positional superiority' ingrained in the psyche of western researchers (see Prior, 2007). Yet, the hallmark of traditional ethnographic research has been intensive, long-term participant-observation in a local community (Turner Strong, 2009). Pauline Turner Strong notes that "this remains a significant mode of research, although today participant-observation often takes place in institutional settings such as tribal schools" (Turner Strong, 2009, p. 256).

Despite increasing interest, school ethnography has it challenges as well. Ángel Díaz de Rada (2007) blames the school for being too bureaucratic in many ways in order to support ethnographic research as it is opposed to the positivist ideal of 'scientific' simplification (see also Erickson \& Gutierrez, 2002). Whereas Martin G. Forsey (2011) points out how a reported sight is commonly considered objective in the western culture and suggest that researchers should apply engaged listening in addition to visual observation. Michael Marker 
(2000, p. 401) for example claims that "if the stories of [indigenous] students could be heard and understood, and if the local political context of their encounter with higher education could be shown, it would unmask a number of presuppositions about ethnicity and education". Although, Marker's research has focused on higher education, we think that his idea about listening and giving space to indigenous peoples' opinions and experiences about education in general is essential and important.

According to our literature survey, recent ethnographic researches at indigenous peoples' schools seem to focus on colonization and its manifestation at school through a variety of perspectives: for example, to identify both curriculum content and pedagogical strategy (London, 2002), culture-based curriculum (Hermes, 2000), the practical establishment of a school for indigenous people (Wardell, 2006), bilingual intercultural education in indigenous schools as an illustration of teacher interpretations of government policy (Valdiviezo, 2009), the dualistic notion of insider/outsider in ethnographic research (Webster \& John, 2010), and physical education at indigenous peoples' school (Fitzpatrick, 2011).

Vuokko Hirvonen (2004/2003) and her work group (Hirvonen, 2003) have studied the realization of the curriculum at the Norwegian Sámi School. Jan Henry Keskitalo (2003, 2009) has been working on the Sámi traditional knowledge's role in the formal education from the perspective of indigenous people. Research aims to implement the Sámi's self-determination because research can be seen as a way of enhancing self-direction, communal empowering, and finding functional strategies.

In this article, we want to review the ethnographer's role in school ethnography carried out at indigenous people's school and especially by a member of indigenous people (see also Keskitalo, 2010; Keskitalo \& Määttä, 2011a; Keskitalo \& Määttä, 2011b; Keskitalo, Määttä, $\&$ Uusiautti 2011). Natives or members of indigenous people have the advantage as they already have the same level with the research target that is other indigenous people; Ray Barnhardt has quite incisively pointed out the difference between "ivory tower knowledge" and traditional, indigenous or real-world knowledge (Barnhardt, 2002, p. 241). Ole F. Lillemyr et al. (2010) have noted that for Indigenous people in particular, cultural values, sense of relatedness and self-determination are important components of school motivation. All these could be studied and enhanced by ethnographic research.

\section{The Ethical Challenges of Researching the Sámi}

According to Jelena Porsanger (2007), certain basic requirements concern indigenous peoples' methodologies, such as research ethics. It appears in the relationship between researchers who are members of indigenous peoples and indigenous peoples that are research targets. These questions are relevant to Sámi epistemology, methodology planning and implementation in Sámi research projects. (Porsanger, 2007.)

Special ethical situation- and context-based challenges embody research on the Sámi. According to Tove Bull (2002), the researcher has to be familiar with the Sámi's history, traditions, culture, and language in order to be able to research the Sámi society. Ethical requirements that concern research among indigenous peoples are, for example, responsibility 
for disseminating information and local participation. All information has to be handled in confidence. Furthermore, participants have to approve the research (Porsanger, 2007). Research results have to be returned to the society where the research was carried out (Bull, 2002; Barron, 2002). In other words, it is important to build and cherish trust between the researcher and research participants. The researcher has to be aware that he/she will meet the research participants later on as well (Nystad, 2003).

Research ethics provides that no one can be hurt based on the research or recognized if that is the agreement. Naturally, there are many ways of doing research and these issues are usually solved case-specifically. Our sample research was conducted in Norway and the research permission for collecting data through videoing required that the research partners had to remain anonymous and unidentifiable from the report. Therefore, when it comes to school research, the researcher has to deliberate how to hide or blot out things from the research based on which the schools could be recognized. It can be done by omitting detailed descriptions of the exterior features of the schools and classrooms or of participants' backgrounds. First and foremost, the challenge in Sámi research is that people who work in the Sámi school context know each other at least somehow (Nystad, 2003). The reason for it is the small collegial community and extensive network of relatives.

In this research, we have followed the framework of Norwegian Data Protection Agency research permission. The partners undersigned agreements. Similarly in this research, the procedures followed the requirements of indigenous peoples' research listed by Bull (2002). People were informed about the research both verbally and in writing. The strength in this research is the first author's own language proficiency: she was able to communicate in the participants' own language whether it was the Norwegian, Sámi, or Finnish language.

The first author is a bearer of the Sámi culture. According to Elina Helander and Kaarina Kailo, Sámi tradition is comparable to scientific knowledge. The Sámi observe their environment as systematically as researchers do. The Sámi knowledge is not, however, more subjective or objective than the knowledge of the dominant population. Everyone interprets things through one's cultural background: the Sámi based on their cultural background whereas the researcher who is a member of the dominant population has his/her cultural background according to which he/she interprets the data. (Helander \& Kailo, 1999.) In this research, the data is emic which means that the researchers do not work as outside observers (see also Pike, 1967). Instead, it is important to bring out researcher's position which is typical of ethnographic and educational-anthropological research. Ethnographic research is a living process where the researcher has to accept threads that lead to several directions (Saikkonen \& Miettinen, 2005). Emic approach in this research was chosen in order to emphasize the indigenous people's own meanings and dissect the culture inside of it and from the point of view of the speakers of the Sámi language and bearers of Sámi culture.

\section{The Purpose of This Article and the Data}

The purpose of this article is to view what are the possibilities to elicit the Sámi school operation through ethnography and to exploit the findings for developing the school. The main questions in this article are the following: 
1) What kinds of roles does the ethnographer possess when conducting Sámi school research?

2) How can ethnography be used for Sámi education?

3) What kind of picture can be drawn of the Sámi School through an ethnographic research?

In her doctoral research, Pigga Keskitalo (2010) studied the cultural sensitivity of the Sámi School in Norwegian Sámi schools. The aim of the original empirical research was to analyze how the school culture and the Sámi culture converge. At the same time, the question of how the school supports the Sámi culture was at the center.

The research material comprised observations and research diary on education provided in the Sámi and Norwegian speaking classes in six Sámi schools in Norway between 2001 and 2007, theme interviews $(\mathrm{N}=15)$ and questionnaires of teachers $(\mathrm{N}=108)$, entries in the research journal, and school documents such as annual plans and curricula, and information distributed by the media. The objective was to understand and present the overall situation of Sámi education. The situation has been examined through two Reforms: Curriculum 1997 Sámi O97S (Gonagaslaš girko-, oahpahus- ja dutkandepartemeanta, 1997) and Sámi Curriculum 2007 Máhttolokten (Máhttodepartemeanta et al., 2008). The research method was school ethnography complemented with a combination of qualitative and quantitative methods.

There are many ways of doing science in the indigenous peoples' school context (Lipka, 1998) and due to the multidimensional nature of the research target, a combination of methods may be needed in order to analyze the field as comprehensively as possible (Teddlie \& Tashakkori, 2003). When studying the meanings in the Sámi curriculum, the ones provided the societal situation have to be taken into consideration: both micro and macro levels involve possibilities and obstacles. Teaching practices are formed, for example, in the confrontation of various cultures (Moilanen \& Räihä, 2001) and therefore, activities connected to teaching may bear different meanings.

The research process was cyclic, including the analysis which overlapped with the course of action (Coffey \& Atkinson, 1996). Research material was categorized and divided into meaningful components but by preserving the connection to entirety. The research material was organized inductively; thus, the analysis is inductive, data-driven (Tesch, 1990).

The research material has been constructed through social communication and therefore knowledge has been created in collaboration with the research partners and assessed by the researchers. Because of the information produced this way in social interaction and co-operation, it seems important to use the term 'research partner' like, for example, Erika Sarivaara (2010) did. In this research, knowledge is considered unique and context-bound.

\section{The Ethnographer at the Sámi School}

Based on our practical and theoretical experience on ethnographic research at the Sámi School, the ethnographer's roles can be illustrated in the following way (see Figure 1). Next, we will introduce these roles in detail and review school ethnography among the Sámi through these roles. 


\section{Macrothink

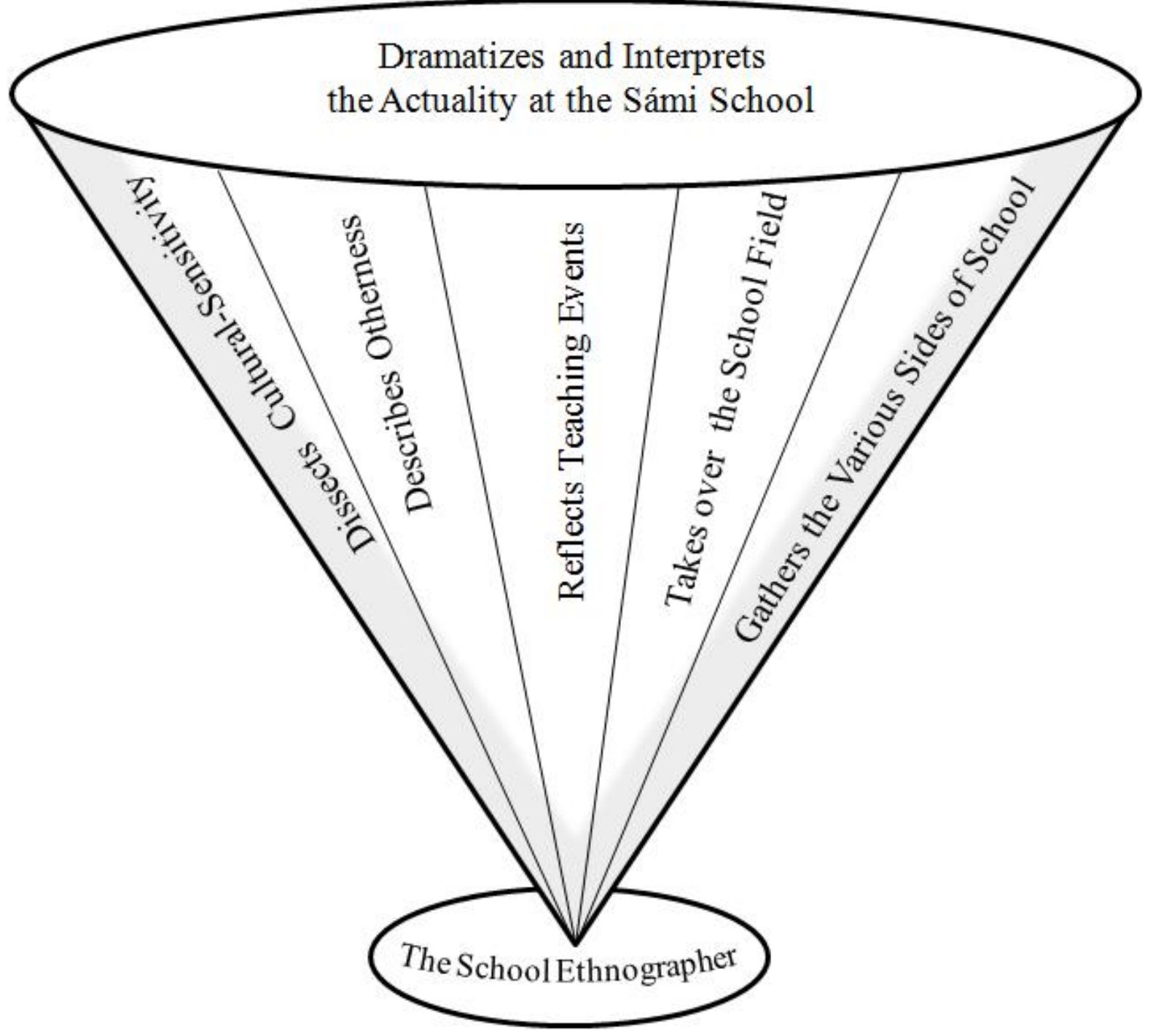

Figure 1. The school ethnographer's roles in Sámi culture (designed by Määttä, 2011)

\subsection{The school ethnographer dissects cultural sensitivity}

The main attention in this research was focused on the relation between socialization and enculturation because dovetailing the traditional and informal education and culture is a central problem in education. The data showed that the way the western school system dominates instruction in the Sámi School is spirally connected with the assimilation, power relations, and socialization process that the Sámi had experienced. The way the school organizes teaching is connected with the historical task of the school, namely, the nature of the school as an organization and the conditions in which Sámi schools provide their instruction.

The problem in many Sámi schools is that their pedagogical arrangements and curricula are similar to other schools. Students are not socialized into their own cultures. Instead, the Sámi School is organized based on the prevailing values. Rather than skills and attitudes, it is affected by the values of one kind of information society. The visual environment at the 
schools was scarce. Neither the pupils' Sámi language nor themes that emerged from the local culture functioned as stimuli. For example, English language group works hung across the walls of the classroom got more visibility than the ones in the Sámi language.

The research material showed that the school culture and Sámi culture did not meet each other sufficiently. In this research, this phenomenon appeared as liminalization where the Sámi School is on the way toward autonomy if the conditions are framed so that they will enable it. However, the question is not that simple: Rauna Kuokkanen (2007) writes about cultural conflicts by criticizing them. According to the author, we simply cannot talk about the collision of cultures because the issue is always linked with power relations as well. In this context, it means that Sámi education lacks self-determination. In ideal circumstances, teaching provided by the school would be based on the values of the surrounding community (see Hollins, 2008).

\subsection{The school ethnographer describes otherness}

Ethnography and anthropological research tradition have been criticized especially for their focus on otherness and pursue of defining primitiveness (see Smith, 1999; Kuokkanen, 2002). The research subjects were described as others, exciting and different. The other was seen as the opposite of oneself and the anthropologist's task was to explain the unfamiliarity into something understandable.

The concept of otherness can be changed along with the change in ethnography. In this research on Sámi education, "the other" lives in the ethnographer's experiences and is researchable, interpretable, and understandable. Minna Opas (2004) considers ethnography as mutual understanding resulting from the negotiations between the ethnographer and research partners. In this research, the days at school consisted of numerous negotiation situations that included mutual experiences.

Our relationship with knowledge is determined by social constructionism and the theory of post-structuralistic reading. In this research, social constructionism means that knowledge is produced in cooperation with the research partners in a circular argument within the theory and that context where the Sámi School is located in. Furthermore, the post-structuralist theory of reading was employed as it has emphasis on the event. Therefore, the ethics of reading refers to the sense of responsibility to the event and uniqueness. In this research, it means that firstly, the researcher has to be aware of her position. Secondly, the researcher cannot manifest what she has seen and experienced but merely, based on the research problems, bring out some practical challenges of the Sámi School.

According to René Gothóni (1997), field work that involves data collection amid other people demands the ability to empathize and diverge. Empathizing means that the researcher tries to put herself in the research partners' position in order to understand them, their behavior, and the context where the Sámi schools operate. Yet, critical research also necessitates the ability to pull away from the research target. The aim is to view issues from further - this is why the ethnographer is supposed to keep a diary, write down observations, and read relevant literature. 


\subsection{The school ethnographer reflects teaching events}

The research process is cyclic in nature. Its every phase involves analysis that proceeds as a reflective process all the way from planning till conclusions. The process in this research started with contextualization and formulating research questions that were specified into their final form during the research process. In order to contextualize the work, it was necessary to get acquaint with the history of Sámi education, its curricula and previous research on the curricula.

In most educational research, reflection is defined as a useful and necessary method helping analyzing teaching and school environment critically. One way of doing this is through using observation and reflection as a way of bringing about change. In school research, reflection forms one important part of pursuing the change. In addition, reflection helps a researcher to demonstrate his/her own action and maturing, and his/her values and to reflect them in relation to the change. (e.g. Oser et al., 1992; Artzt \& Armour-Thomas, 2002.)

In this research, the researcher reflected events that took place at school in order to perceive the present state of Sámi education. At the same time, her understanding about the issues that were significant to the research strengthened (see Keskitalo, 2010). When a researcher reflects his/her own action profoundly and frequently, the researcher may, in a manner of speaking, lose his/her grip of the core concept of the research. Therefore, reflection is a dialogue between questions and answers that the researcher poses to himself or herself. (e.g. Osterman \& Kotkamp, 1993.)

\subsection{The school ethnographer takes over the school field}

In ethnographic research, working in the field in indigenous environment is a central concept. When researchers work in the field, they are in some cases somewhere, elsewhere, far away. They have to travel to get in the field, spend a long time researching - maybe some weeks or months - during which researchers observe the research target trying to understand its events and significant features. (Syrjäläinen, 1994.)

An ethnographer who researches the Sámi School has a structurally wide field to study: it includes students, teachers, text books, teaching arrangements, and the community outside the school. The ethnographer focuses on the everyday life at school in order to understand the daily practices and processes; and follows the events and teaching in the classroom by observation. Yet, it is impossible to observe everything that takes place in the field.

Therefore, it is important that the researcher defines the limits for the analysis carefully. In this research, the Sámi school research was focused on the following themes (cf. Rantala, 2005):

1) The school as material and economic environment (the equipment at school, learning materials)

2) The school as physical space (school buildings, teachers' room, classrooms, break/playtime or PE facilities) 
3) The school as cultural and social environment (the cultural-sensitivity of school, the position of the school in the community)

4) The school as linguistic and semantic environment (what language is used, how people talk about the school)

5) The school as the environment for the interaction between people who work there (the interaction between teachers and students and other personnel, communication between the school and parents)

6) The school as the learning environment constructed by teaching arrangements and learning situations (the number of students per classroom, timetables, the length of lessons, teaching methods, project and theme work)

7) The school as space of discipline and control (the school regulations, means of controlling students)

Paul Atkinson (1992) divides the field work phase into a three-part process. In the first phase, the field and its events observed by the ethnographer are described. In the next phase, the field is formed into writing that is not limited within the field and home any longer but is mixed with the various phases of the research and writing process (Gupta \& Ferguson, 1996). In this school ethnography, the time the researcher spent at school is not long but versatile data form a triangulation in the research. Data triangulation refers to a multiple perspective in which various methods and approaches are combined (Saaranen-Kauppinen \& Puusniekka, 2006).

\subsection{The school ethnographer pulls together the various sides of school}

One of the features in this research was the abundance of the phenomena in the indigenous peoples' teaching context: the connection between the teacher, teaching, guiding, and learning is complicated. Yet, the aim of classroom research is to perceive the connection of guiding and teaching with students' learning (Anderson \& Burns, 1989) although it is challenging to describe all factors that affect the interaction between the teacher and the student group (Heikkilä \& Sahlström 2003; Sahlström, 2008a, 2008b). In addition, students' learning is a sum of several factors and it is not possible to completely or comprehensively observe the teacher's action in teaching (Anderson \& Burns, 1989).

The purpose was to create as comprehensive picture about the Sámi School and education as possible through diverse data collection: as if the ethnographer was assembling a jigsaw puzzle when conducting school research (see also Denzin \& Lincoln, 2000). The pieces of this research cover the video data, interviews, questionnaires, diary, and curricula. The research is analyzed by explaining how the pieces were selected in the research.

Furthermore, ethnography can be suitable method for observing the unconscious work at classroom. According to Neil Harrison (2005, p. 879) indigenous students are already learning outside an assimilation of the position of a non-indigenous, usually western, teacher. This learning is produced through the discourse of negotiation, a meta-language that is produced outside the methodologies and theories and beyond the conscious mind of the 
student. (see also Regalsky \& Laurie, 2007.)

According to Ulla-Maija Salo (1999), the focus, analysis methods and the manner of representation have to specified and defined several times during ethnographic writing. This notion is valid in this research as well: it was worth realizing that the ethnographic data is not dissected at once but it can be viewed in new connections and from new perspectives later on. The manifold nature of the context and many different approaches expose the research to disorder but it has to be considered as one characteristic of ethnography.

Furthermore, the form and outline of the research are ambulatory concepts. In this process, the original research was molded into the present form. When dissecting the themes all over again, the approaches are different. According to Amanda Coffey, the ethnographer's role has to be seen active, information productive and participative because of the social perspective of the field work. (Coffey, 1999.) In this research, besides speech, actions, gestures, and movements were significant. As several conversations may take place in the classroom at the same time, the researcher had to select such entity that she had understood to be documented.

In the classroom, teaching happens formally through teaching arrangements and realization. In addition, various encounters and situations take place in the classroom and do not necessarily have anything to do with the formal teaching and learning. To the ethnographer, the context is a real challenge exactly because of the multidimensional activities in the classroom. It is also possible that acts and action are in danger of remaining ignored because people's speech and opinions come more clearly in the center.

\subsection{The school ethnographer dramatizes and interprets the actuality at the Sámi School}

In ethnographic research, pictures, texts, conversations, and experiences are mixed up and form a new entity: an interpretation about what really happens at the Sámi School. Norman K. Denzin and Yvonna S. Lincoln (2000) use the term 'montage' to describe a stage where researchers place the pieces they use for describing the phenomenon they have studied. They situate actors on the research stage and select the actors' lines from the data. The drama is not authentic because researchers have selected the lines and scenes that represent the research target the best in their opinion. The happenings do not move on as a sequential continuum on stage but as various scenes and entrances into different situations. One of the most important tasks of the researchers and dramatizers is therefore editing (see Rantala, 2007).

The interpretation in this research revealed that the Sámi School did not appear culturally very sensitive. The problem of the school is that it cannot solve the ways how teaching is arranged in the western school world referring, for example, to teacher-centered teaching which is tied to text books. Subject and time allocation epitomizes this kind of the teaching arrangement as well. Organizing teaching with the focus on a holistic approach would suit Sámi education better. Then the school schedules, conception of space and idea of learning would become more similar to the typical manner of surrounding environment. The working methods at school should be developed into more pupil-centered than before and learning environments should be seen as wider than just a classroom. For example, local people and nature could be exploited in teaching remarkably more than they are today. To enhance 
pupils' proficiency in Sámi language, it would also be important that the language would be more visible in schools and classrooms. (see also Hertting \& Alerby, 2009.)

In this dramatization, school rituals played a significant role as well. Educational Anthropologist Christoph Wulf (2008) considers rituals as a part of the society. Rituals may have either an including or excluding role. Moreover, rituals may involve stereotypes. Rituals are social forms where social action and its manifestations produce rules and hierarchies. (Wulf, 2008.) Also teaching epitomizes the transmission of rituals. Rituals appear in the everyday life at school in various events and shifts and they help keeping the system together. That exact feature seems to be the primary factor that separates school from enculturation. Along with the original research, it started to seem that it was the question about a larger entity than just school arrangements, such as keeping the doors locked, teacher-led instruction, and placing desks apart. Maintaining the charade does indeed necessitate routines. School days start in a certain, repetitive way: the first lesson takes place, then a break, the second lesson, the third and so on.

Yet, this kind of school routine is not in accordance with the Sámi worldview. Nor do the Sámi have a school history of their own that would have been formed from their own starting point. School is an unfamiliar concept and institution for the Sámi: originally, it was brought to the Sámi community by outsiders (Sara, 1987). The tradition of Sámi education is relatively short due to which there are deficiencies at every level. Among others, these deficiencies are the constant lack of qualified teachers and cultural sensitive learning material in the Sámi language. However, the situation has improved little by little because of teacher education and learning materials provided in the Sámi language. As the Sámi do not have widely materialized self-governance, they have not been able to develop the Sámi School from their own premises. Therefore, the present school culture as such does not meet the Sámi’s needs sufficiently.

\section{The Reliability of the Research}

Especially in qualitative research, the reliability of the research should be evaluated at each phase of the research. The research can be evaluated with four concepts: inner validity, outer validity, reliability, and objectivity or - as Lincoln and Guba (1985) further suggest concerning qualitative research - with credibility, transferability, dependability, and confirmability. In this research, the data was variform and therefore, the research could be evaluated through the criteria designed especially for mixed methods research. Mixed methods research can be evaluated with independence of the methods, insulation of the data, interdependence of the methods, integration, and the aim of the research (whether it is comparability or contrast) (Brewer \& Hunter, 1990). Thus, the reliability of the research can be strengthened with a variety of data, researcher, or theory (Johnson \& Onwuegbuzie, 2004; Lincoln \& Guba, 1985) and the first option was used in the research in question - although naturally all parts of the research have to be executed carefully because mixing methods does not compensate for badly performed parts of the research.

The researcher's role should not be forgotten either: According to Michael Quinn Patton (1990), it is all about the researcher's reliability because the researcher is the ultimate 
instrument and the core of the analytic process. Furthermore, in school ethnography, the researcher always affects the action in a classroom with her presence to some extent. In this research, the teachers were asked to describe how much the researcher actually affected in the classroom in order to check the inner validity of the research. In other words, it was about the Hawthorne effect (see also Adair, 1984; Uusikylä, 1980).

It is worth noticing that the researcher did not spend a long time at school and thus it is difficult to assess the researcher's influence in the classroom in the long term. During the first days at school, the Hawthorne effect was evident but eventually, students got used to the researcher's presence. Some students reacted strongly while other did not react at all. The researcher's presence could bother them: it was manifested by glancing at the camcorder constantly and asking whether the camcorder was on or off. Sometimes, the researcher's presence had positive effect too as her presence could calm down the atmosphere in the classroom.

In this school ethnography, observation was participative and partly active. Especially at the children's school level, students could ask the researcher for advice and therefore, she acted as an ancillary teacher. Similarly, during breaks or playtime, students could ask the researcher to participate in playing or games. At the middle school or juvenile school level, the researcher worked mainly as an outside observer.

School ethnography is unpredictable and this feature manifested itself in this research as well. The researcher could not know beforehand how long the process would take in reality. Informing people about the research process, acquiring permissions, and recruiting the schools for the research took time before carrying out the actual research. The purpose of the research and its course were openly described at the phase of recruiting and visiting the schools. Did the teachers change the practices due to it? Although teachers would have concentrated on planning their teaching and working methods more than usually during the lessons that were observed, they would have only showed their proficiency.

Often, the time spent among the research target is evaluated in ethnographic research. However, according to Martin G. Forsey (2010), the outcomes of ethnographic research should be judged more by the quality of the representation of the lived reality than with how much time one spent in living this with the persons captured in ethnographic text. In other words, too often the research is assessed according to how it was done rather than by the strength of its findings and the skill of the analysis. This was the aim of this research as well and it closely connected with the highest role of an ethnographer as the dramatizer described in the previous chapter. The reliability of the research was also strengthened by careful preparation before carrying out the observations by familiarizing with the written curriculum and research on curricula, discussing with the teachers, and becoming acquainted with the school plans and documents.

Observational research has its problems, too, because events that take place in the classroom are difficult to interpret because of their multidimensional nature. In addition, researching how the curriculum is realized in practice requires plenty of time and is laborious (Rønning, 2002). Indeed, studying the conflict of socialization at school is a many-sided target because 
socialization and curriculum theories are multidimensional as well (Øzerk, 2006).

It is quite typical of qualitative research that the research theme is defined, specified, and altered all the time. During this research process, many sides of the research were specified in the text and the researcher's thinking constantly. The research shaped from a fragmented one into more structured. Little by little, the researchers perceived better what the school change is eventually about. School ethnography appeared a functional means to research Sámi education and culture and to contribute to the aspirations of changing the teaching culture and classroom practices.

\section{Discussion}

According to Skeggs (1999), ethnography is a research process where the researcher brings forth his/her relation to power questions, ethics, and researcher's responsibility. Ethnography aims at describing and understanding cultural experiences, including classroom situations. Furthermore, ethnography can be empowering because it gives space to teachers' voice (Spindler \& Hammond, 2000). Revealing and contemplating the power relations are important themes in the discourse about indigenous peoples; for example, researching the limitations, order, and practices at the Sámi School.The meanings can be analyzed by conceptualizing the context where the school functions in daily life. Meanings and cultural relationships are intertwined and thus bring out the power questions (Lehtonen, 2004/1996).

New kinds of approaches are needed to canvassing and figuring out the societal power structure (Kuokkanen, 2008). Also, James Collins (2009) argues that we have to consider multiple levels of social and institutional structure as well as micro-analytic communicative processes and cultural practices in education and society with new kinds of tools. Indigenous peoples' clearly have their own kind of knowledge, value, and ontological theories (Kuokkanen, 2000; 2007). Indigenous peoples have their own ways of determining what is necessary to know: they have a special understanding about the world and life. Nevertheless, not even ontology and ethics are common to all indigenous peoples. According to Nils Oskal, it is not possible to have a special and tenable methodology. Hermeneutically enriched research requires scientific humbleness, openness, and courage. (Oskal, 2008.) Indigenous peoples' worldviews cannot be ignored either (Kuokkanen, 2007).

Linda Tuhiwai Smith dissects critically the western research philosophy and history. According to Smith, it is necessary to decolonize research methods because of the European imperialism and Smith does represent some options that could enable moving from imperialism toward post-colonization and abandoning western paradigms. Indigenous peoples' research should help peoples to attain self-governance through empowerment, survival, development, mobilization, changing, and decolonization. (Smith, 1999.) There is a need to decolonize the Sámi School - or turn it toward Sáminess as Balto (2008) and Hirvonen (2003b, 2004/2003) claim.

The epistemological starting point in this research was founded on the principles of minority research. According to these principles, everyone has knowledge of something and it is always produced in cooperation with others. The question is about various ideas of 
knowledge. (Mohanty, 1994.) In this research, methodological points of view were closely connected with the information production, diversity, power relations, and paradigmatic questions (see Eddy, 1997; Ford, 1997; Kuokkanen, 2000; Spindler, 1997; Wolcott, 1997; Wulf, 2002).

In the educational-anthropological approach, the familiar is seen as unfamiliar in order to perceive the hidden meanings. In order to change things, the special characteristics of the target have to be brought out. Therefore, the original research introduced in this article aimed at describing the special features of Sámi education extensively. In addition, openness is typical of ethnography. The research is not grounded on certain hypotheses but the data is derived from cultural context. The most important task is to create a coherent idea how to raise children in a more diverse society than ever before. (Spindler \& Hammond, 2000.)

The concepts of transculturation and inter-culturation describe the transformation from cultures living side by side toward inter-culturalism. The diversity of the Sámi School originates in the tradition of colonization and the decolonization process that follows it. The Sámi's political awakening, sámi lihkadus, and cooperation with indigenous peoples embody this awakening. Sámi communities are relatively large because of the geographical reach of their settlement. Inner, cultural, and livelihood related differences are also great; in addition, the diversity manifests itself as multilingualism (see Helander, 1984; McLaughlin, 1987). The local multiculturalism consists not only of the Sámi, Finns, Norwegians, and Kvens but also other ethnic minorities: all these languages increase the language-sociological richness in the everyday life at the Sámi School. Moreover, the political situation including legislation and human rights has to be taken into consideration. In the school context, ecological and cultural factors affect students' cognitive, affective, and social development (Seitamo, 1991). Linguistic and cultural diversity provides that teaching arrangements are student-sensitive. It refers, for example, to such activities where the teacher notices students from their points of view and encourages them to develop their own thinking (Zahorik, 1975). In addition, a concept of 'family literacy' has been introduced to refer to the teachers' capability of building effective relationships between home, school and community (Cairney, 2001) - and in the context of indigenous peoples' schooling together with the dominant culture the concept appears quite relevant.

The context of the Sámi School may be viewed through transculturation as it explains transition as the foundation of social continuity. The purpose of the Sámi School is not to homogenize culture so that the dominant culture would play the main role. Instead, heterogenization, new kind of diversity, should be emphasized. As a salient part of transculturation, the extrinsic and local are mixed and this interaction produces new re-contextualizations. Therefore, the concept of transculturation is important as it helps understanding the situations where cultures confront and proved a new perspective to the power relations and decolonization processes. (Judén-Tupakka, 2003.) Furthermore, in the diverse Sámi School context, it is important to be aware of the differences in experiential worlds that affect individuals' processes of adjustment, integration, and ethical diverging (Eidheim, 2007). For diversity, it is important that the Sámi School context is not simplified or categorized too radically through the emphases in the definition of Sáminess. 
Doing ethnography in Sámi School context begins with understanding indigenous pedagogy. Indigenous pedagogy means pedagogy that has emerged from the local context of practice (see Young, 2010, p. 2): How could one write ethnography in a manner that admires indigenous cultures? Ethnography can help designing an indigenous educational model that is culturally responsive, and rigorous, and supports students' success. In today's world, globalism and multi-culturalism place various challenges for education, and culturally sensitive education is one of the most important issues concerning these challenges (see also Labaree, 2003; Schoorman \& Bogotch, 2010). Therefore, the education of minorities and indigenous peoples is of great importance as well because of their endangered and liminal position in the society.

The need for conducting research ordered by not only the outsiders but by the indigenous peoples themselves is obvious. Many indigenous peoples' researchers think that theory as such is not bad but important also to indigenous peoples because it helps them to understand reality, make hypotheses about the world where they live and, first and foremost, create strategies and control criticism toward indigenous peoples (Smith, 1999). According to Maori Researcher Kathy Irwin (1992), theory is not any academic luxury but a necessary part of revolutionary equipment. It is a tool that can harness the powers of mind, heart, and soul. Irwin thinks that indigenous peoples do not need outsiders to develop methods that would help them to understand who they are. Indigenous peoples can do it by themselves. The method designers have always possessed the true power - and indigenous peoples may also have this power. (Irwin, 1992; see also Kuokkanen 2002.)

\section{References}

Act of 12. No. 56 concerning the Sameting (the Sami parliament) and other Sami legal matters (the Sami Act). (1987). Regjeringen. June 1987. [Online] Available: http://www.regjeringen.no/mobil/en/doc/laws/Acts/the-sami-act-.html?id=449701 (May 29, 2011).

Adair, G. (1984). The Hawthorne effect: A reconsideration of the methodological artifact. Journal of Applied Psychology, 69, 334-345. http://dx.doi.org/10.1037/0021-9010.69.2.334

Anderson, L. W., \& Burns, R. B. (1989). Research classrooms. The study of teachers, teaching, and instruction. Oxford: Pergamon Press.

Anttonen, T. (2004). Miehet internetissä - Virtuaalietnografia miessairaanhoitajaopiskelijoiden seksuaaliterveysteeman opiskelusta [The men on the Internet - Virtual ethnography about male nurse students' sexual health education]. (Acta Universitatis Tamperensis, No. 1054.) Tampere: University of Tampere.

Artzt, A. F., \& Armour-Thomas, E. (2002). Becoming a reflective mathematics teacher: $a$ guide for observations and self assessment. Mahwah: Lawrence Erlbaum Associates.

Atkinson, P. (1992). Understanding ethnographic texts. Qualitative research methods 25. Newbury Park: Sage.

Atkinson, P. (2004). Performing Ethnography and the Ethnography on Performance. British 
Journal of Sociology of Education, $25 \quad$ (1), 107-114. http://dx.doi.org/10/1080.0142569032000155980

Atkinsson, P., \& Hammersley, M., (1994). Ethnography and participant observation. In N. Denzin, \& Y. Lincoln (Eds.), Handbook of qualitative research (pp. 248-261). Thousand Oaks: Sage.

Balto, A. (1997). Sámi mánáidbajásgeassin nuppástuvvá [Sámi childrearing in change]. Oslo: ad Notam Gyldendal.

Balto, A. (2008). Sámi oahpaheaddjit sirdet árbevirolaš kultuvrra boahttevaš buolvvaide: dekoloniserema akšuvdnadutkamuš Ruota beale Sámis [Sámi teachers transforming traditional culture to the next generations: action research about decolonization in Sápmi of Sweden]. Guovdageaidnu: Sámi allaskuvla.

Barnhardt, R. (2002). Domestication of the ivory tower: institutional adaptation to cultural distance. Anthropology \& Education Quarterly, 33(2), 238-249. http://dx.doi.org/10.1525/aeq.2002.33.2.238

Barron, A. (2002). Traditional knowledge, indigenous culture and intellectual property rights. In Samisk forskning og forskningsetikk [Sámi research and research ethics] (pp. 56-87). (Publications No. 2.) Oslo: Forskningsetiske komiteer.

Brewer, J., \& Hunter, A. (1990). Multimethod research. A synthesis of styles. Thousand Oaks: Sage.

Bull, T. (2002). Kunnskapspolitikk, forskningsetikk og det samiske samfunnet [Knowledge politics, research ethics and the Sámi society]. In Den nasjonale forskningsetiske komité for samfunnsvitenskap og humaniora (NESH) [The National Research Ethical Committee for Social Sciences and Humanities] (Ed.) Samisk forskning og forskningsetikk [Sámi research and research ethics] (pp. 6-21). Oslo: Forskningsetiske komiteer.

Cairney, T. H. (2002). Bridging home and school literacy: in search of transformative approaches to curriculum. Early Child Development and Care, 172 (2), 153-172. http://dx.doi.org/10.1080=03004430290013317

Coffey, A. (1999). The ethnographic self: fieldwork and the representation of identity. London: Sage.

Coffey, A., \& Atkinson, P. (1996). Making sense of qualitative data: complementary research strategies. Thousand Oaks, CA: Sage.

Collins, J. (2009). Social reproduction in classrooms and schools. Annual Review of Anthropology, 38, 33-48. http://dx.doi.org/10.1146/annurev.anthro.37.081407.085242

Creswell, J. W. (2003). Research design: qualitative, quantitative, and mixed methods approaches. Thousand Oaks: Sage.

Denzin, N., \& Lincoln, Y. (2000). Introduction: The discipline and practice of qualitative research. In K. Denzin \& Y. Lincoln (Eds.), Handbook of qualitative research (pp. 1-28). 
Thousand Oaks: Sage.

Díaz de Rada, A. (2007). School bureaucracy, ethnography and culture: Conceptual obstacles to doing ethnography in schools. Social Anthropology/Anthropologie Sociale, 15 (2), 205-222. http://dx.doi.org/10.1111/j.0964-0282.2007.00017.x

Eddy, E. M. (1997). Theory, research, and application in educational anthropology. In G. D. Spindler (Ed.), Education and cultural process. Anthropological approaches (pp. 4-25). (3 ${ }^{\text {rd }}$ ed.) Prospect Heights: Waveland Press.

Eidheim, H. (2007). Terapiatapahtuman havainnoinnista, kulttuurisesta ja ammatillisesta kompetenssista [About the orservation of therapy event, cultural and professional competence]. In H. Eidheim \& V. Stordal (Eds.), Kulttuuritietoisia kohtaamisia. Sosiaali- ja terapiatyöstä saamelaisalueella [Culture-conscious encounters. About social and therapy work in the Sámi district] (pp. 53-69). Rovaniemi: Pohjois-Suomen sosiaalialan osaamiskeskus.

The encyclopaedia of Sámi culture. [Saamelaiskulttuurin ensyklopedia]. (2003). Helsinki: The University of Helsinki. [Online] Available: http://www.helsinki.fi/ sugl_smi/senc/esittely.htm (December 1, 2009)

Erickson, F., \& Gutierrez, K. (2002). Comment: culture, rigor, and science in educational research. Educational Researcher, $31 \quad$ 21-24. http://dx.doi.org/10.3102/0013189X031008021

Eräsaari, L. (1994). Millainen tekotuote etnografia on [What kind of artificial product ethnography is]? Janus, 2 (4), 366-372.

Fitzpatrick, K. (2011). Stop playing up! Physical education, racialization and resistance. Ethnography, 12 (2), 174-197. http://dx.doi.org/10.1177/1466138110362014

Ford, R. (1997). Educational anthropology. Early history and educationist contributions. In G. D. Spindler (Ed.), Education and cultural process. Anthropological approaches (pp. 26-45). ( $3^{\text {rd }}$ ed.) Prospect Heights: Waveland Press.

Forsey, M. G. (2010). Ethnography as participant listening. Ethnography, 11 (4), 558-572. http://dx.doi.org/10.1177/1466138110372587

Geertz, C. (1973). The interpretation of cultures. New York: Basic Books.

Geertz, C. (2010). Life among the anthros. Princeton: Princeton University Press.

Gerstl-Pepin, C., \& Gunzenhauser, M. (2002). Collaborative team ethnography and the paradoxes of interpretation. Qualitative Studies in Education, 15 (2), 137-154. http://dx.doi.org/10.1080/09518390110111884

Gonagaslaš girko-, oahpahus- ja dutkandepartemeanta [The Royal Church, Education and Research Ministry]. (1997). 10-jagi vuoddoskuvlla sámi oahppoplánat. (O97S) [10-year Primary School Curriculum]. Oslo. 
Gordon, et al. (2000). Koulun arkea tutkimassa - kokemuksia kollektiivisesta etnografiasta [Researching the school's daily life - the collective experience of ethnography]. Naistutkimus, 13 (19), 17-31.

Gordon, T., Holland, J., \& Lahelma, E. (2001). Ethnographic research in educational settings. In P. Atkinson, A. Coffey, S. Delamont, J. Lofland, \& L. Lofland (Eds.), Handbook of ethnography (pp. 188-203). London: Sage.

Gothóni, R. (1997). Eläytyminen ja etääntyminen kenttätutkimuksessa [Empathy and distancing the field study]. In A. Viljanen \& M. Lahti (Eds.), Kaukaa haettua. Kirjoituksia antropologisesta kenttätyöstä [Far-fetched. The writings of an anthropological field work] (pp. 136-148). Helsinki: Suomen Antropologinen Seura.

Gupta, A., \& Ferguson, J. (1996). Discipline and practice: "The Field" as site, method, and location in anthropology. In A. Gupta \& J. Ferguson (Eds.), Anthropological locationsboundaries and grounds of a field science (pp. 1-46). Berkeley: University of California Press.

Harrison, N. (2005). The learning is in-between: the search for a metalanguage in indigenous education. Educational Philosophy and Theory, 37 (6), 871-884. http://dx.doi.org/10.1111/j.1469-5812.2005.00163.x

Heikkilä, M., \& Sahlström, F. (2003). Om användning av videoinspelning i fältarbete [About the use of videoing in field work]. Pedagogisk Forskning i Sverige, 8 (1-2), 24-41.

Helander, E. (1984). Om trespråkighet: en undersökning av språkvalet hos samerna i Övre Soppero [About trilingualism: a study on language selection among the Sámi in Övre Soppero]. Stockholm: Almqvist \& Wiksell International.

Helander, E., \& Kailo, K. (1999). Ei alkua ei loppua. Saamelaisten puheenvuoro [No begin no end. Sámi people speak up]. Helsinki: LIKE.

Henriksen, J. B., Scheinin, M., \& Åhrén, M. (2005). Pohjoismaisen saamelaissopimuksen taustamateriaalia. Pohjoismainen saamelaissopimus: 13. marraskuuta 2002 nimitetyn suomalais-norjalais-ruotsalais-saamelaisen asiantuntijatyöryhmän 27. lokakuuta 2005 luovuttama luonnos [Background Material of the Nordic Sámi Convention. Nordic Sámi Concention: An outline handed in 27 Oct 2005 by a Finnish-Norwegian-Swedish-Sámi work group established in 13 Nov 2002] (pp. 263-314). Oslo: Arbeids- og inkluderingsdepartementet. [Online] Available: http://www.regjeringen.no/Upload/AID/temadokumenter/sami/sami_samskonvensjonen_fins k_H-2183\%20F.pdf (April 9, 2011)

Henson, R. K., Hull, D. M., \& Williams, C. S. (2010). Methodology in our education research culture: toward a stronger collective quantitative proficiency. Educational Researcher, 39 (3), 229-240. http://dx.doi.org/10.3102/0013189X10365102

Hermes, M. (2000). The scientific method, Nintendo, and Eagle feathers: rethinking the meaning of "culture-based" curriculum at an Ojibwe tribal school. Qualitative Studies in 
Education, 13 (4), 387-400.

Hertting, K., \& Alerby, E. (2009). Learning without boundaries: to voice indigenous children's experiences of learning places. The International Journal of Learning, 16(6), 633-647.

Hirvonen, V. (Ed.). (2003). Sámi skuvla plánain ja praktihkas: mo dustet O97S hástalusaid? Reforpma 97 evalueren [Sámi School in Plans and Practice: how to ensure the challenges of O97S? Reform 97 evaluation]. Guovdageaidnu: CálliidLágádus.

Hirvonen, V. (2004/2003). Sámi culture and the school: Reflections by Sámi teachers and the realization of the Sámi School. An Evaluation Study of Reform 97. Karasjok: ČálliidLágádus.

Hoëm, A. (1978). Sosialisering: en teoretisk og empirisk modellutvikling [Socialisation: an theoretical and empiric model elaboration]. Oslo: Universitetsforlaget.

Hollins, E. R. (2008). Foreword. In H. Kohl (Ed.), Culture in school learning: revealing the deep meaning (pp. xi-xii). New York: Routledge.

Hostetler, K. (2005). What is "good" education research? Educational Researcher, 34 (6), 16-21. http://dx.doi.org/10.3103/0013189X034006016

ILO no. 169. (1989). United Nations.

Irwin, K. (1992). Towards theories of Maori feminisms. In R. du Plessis (Ed.), Feminist voices: women's studies texts for Aotearoa/New Zealand (pp. 1-21). Auckland: Oxford University Press.

James, A. (2001). Ethnography in the study of children and childhood. In P. Atkinson et al. (Eds.), Handbook of ethnography (pp. 246-257). London: Sage.

Johnson, R. B., \& Onwuegbuzie, A. J. (2004). Mixed methods research: a research paradigm whose time has come. Educational Researcher, 33 (7), 14-26. http://dx.doi.org/10.3102/0013189X033007014

Judén-Tupakka, S. (2003). Kasvatusantropologia - tutkimuskohteena siirtymärituaalit, enkulturaatio ja kulttuuritransitio [Educational anthropology - transitional rituals, enculturation, and cultural transition as a research target]. In H. Sinevaara-Niskanen \& R. Rajala (Eds.), Kasvatuksen yhteisöt - uupumista, häirintää vai yhteisöllistä kasvua? [Educational communities - fatigue, disturbance, or communal development?] (pp. 311-323). Publications of the University of Lapland, No. 3.) [Online] Available: http://ktk.ulapland.fi/kasvatuspaivat/index.htm (November 16, 2005)

Keskitalo, J. H. (2003). School Improvement among indigenous groups of the Circumpolar North. In V. Hirvonen (Ed.), Sámi áddejupmi ja sámi skuvla [Sami understanding and Sami education] (pp. 45-50). Nordic Sámi Educational Research Conference. Kautokeino November 7th and 9th 2001. Guovdageaidnu: Sámi allaskuvla/Saami university College.

Keskitalo, J. H. (2009). Sámi máhttu ja sámi skuvlamáhttu: teorehtalaš geahcastat [Sámi knowledge and Sámi school knowledge: theoretical overview], Sámi dieđalaš áigečála, 1-2, 
$62-75$.

Keskitalo, P. (2010). Saamelaiskoulun kulttuurisensitiivisyyttä etsimässä kasvatusantropologian keinoin [Cultural sensitivity in the sámi school through educational anthropology]. (Dieđut 1/2010.) Guovdageaidnu: Sámi allaskuvla.

Keskitalo, P., \& Määttä, K. (2011a, accepted). How do the Sámi culture and school culture converge - or do they? The Australian Journal of Indigenous Education.

Keskitalo, P., \& Määttä, K. (2011b, accepted). The linguistic special features of the Sámi education. Indian Journal of Applied Linguistics.

Keskitalo, P., Määttä, K., \& Uusiautti, S. (2011, accepted). Toward the practical framework of Sámi education. British Journal of Educational Research.

King, L., \& Schielmann, S. (2004). The challenge of indigenous education: practice and perspectives. Paris: Unesco.

Kohonen, V., \& Leppilampi, A. (1992). Kohti yhteistoiminnallista koulukulttuuria koulunjohdollinen koulutus uusien haasteiden edessä [Towards cooperational school culture school administration education facing the new challenges]. In K. Hämäläinen \& A. Mikkola (Eds.), Koulun kehittämisen kansainvälisiä virtauksia [International trends in developing the school] (pp. 31-56). Helsinki: VAPK-publication.

Kuokkanen, R. (2000). Towards "an indigenous paradigm" from a Sami perspective. The Canadian Journal of Native Studies, 20 (2), 411-436.

Kuokkanen, R. (2002). Alkuperäiskansojen diskurssi ja dekolonisaatio [Indigenous discourse and decolonization]. In S. Lakomäki \& M. Savolainen (Eds.), Kojootteja, Sulkapäähineitä, uraanikaivoksia. Pohjois-Amerikan intiaanien kirjallisuuksia ja kulttuureja [Coyotes, feather hats, Uranium mines. North American Indian literatures and cultures] (pp. 240-264). Oulu: University of Oulu.

Kuokkanen, R. (2007). Reshaping the university: responsibility, indigenous epistemes, and the logic of the gift. Vancouver: UBC Press.

Kuokkanen, R. (2008). Sami higher education and research: toward building a vision for future. In M. Henry (Ed.), Indigenous peoples: self-determination - knowledge - indigeneity (pp. 267-286). Amsterdam: Eburon.

Labaree, D. F. (2003). The peculiar problems of preparing educational researchers. Educational Researcher, 32 (4), 13-22. http://dx.doi.org/10.3102/0013189X032004013

Lappalainen, S. (2006). Kansallisuus, etnisyys ja sukupuoli lasten välisissä suhteissa ja esiopetuksen käytännöissä [Nationality, ethnicity and gender in children's peer relations and preschool practices]. Helsinki: University of Helsinki.

Lehtonen, M. 2004 (1996). Merkitysten maailma [The world of the meanings]. (5th ed.) Tampere: Vastapaino. 
Lillemyr, O. F., Søbstad, F., Marderb, K., \& Flowerday, T. (2010). Indigenous and non-Indigenous primary school students' attitudes on play, humour, learning and self-concept: a comparative perspective. European Early Childhood Education Research Journal, 18 (2), 243-267. http://dx.doi.org/10.1080/13502931003784396

Lincoln, Y. S., \& Guba, E. G. (1985). Naturalistic inquiry. Thousand Oaks: Sage.

Lipka, J. (1998). Appendix: methodology. In J. Lipka, G. V. Mohatt, \& the Ciulistet Group (Eds.), Transforming the culture of schools. Yup'ik Eskimo examples (pp. 201-228). Mahwah: Lawrence Erlbaum Associates.

London, N. A. (2002). Curriculum convergence: an ethno-historical investigation into schooling in Trinidad and Tobago. Comparative Education, 38 (1), 53-72. http://dx.doi.org/10.1080/03040060120103856

Länsman, A.-S. (2008). Kenelle saamentutkija tutkii? [Whom does a Sámi researcher do research for?] In K. Lempiäinen, O. Löytty, \& M. Kinnunen (Eds.), Tutkijan kirja [The researcher's manual] (pp. 87-98). Tampere: Vastapaino.

Malinowski, B. (1984). Argonauts of the Western Pacific: an account of native enterprise and adventure in the Archipelagos of Melanesian New Guinea. Prospect Heights: Waveland Press.

Marker, M. (2000). Lummi identity and white racism: when location is a real place. Qualitative Studies in Education, 13 (4), 401-414.

Máhttodepartemeanta, Sámediggi \& Oahpahusdirektoráhtta. (2008). Máhttolokten: Sámi Oahppoplánabuvttus [Knowledge Raising: The Sámi Curriculum]. Oslo: Oahpahusdirektoráhtta. [Online]Available: http://www.sametinget.no/kunde/filer/Kunnskapsloftet\%20samisk_NORDSAMISK(1).pdf (March 10, 2010)

McLaughlin, B. (1987). Theories of second-language learning. London: Edward Arnold.

Metsämuuronen, J. (2006). Laadullisen tutkimuksen perusteet [The basics of qualitative research]. In J. Metsämuuronen (Ed.), Laadullisen tutkimuksen käsikirja [Handbook of qualitative research] (pp. 79-144). Helsinki: International Methelp.

Mohanty, C. T. (1994). On race and voice: challenges for liberal education in the 1990s. In H. A. Giroux \& P. McLaren (Eds.), Between borders: pedagogy and the politics of cultural studies (pp. 146-166). New York: Routledge.

Moilanen, P., \& Räihä, P. (2001). Merkitysrakenteiden tulkinta [Interpretation of the significance of the structures]. In J. Aaltola \& R. Valli (Eds.), Ikkunoita tutkimusmetodeihin II - näkökulmia aloittelevalle tutkijalle tutkimuksen teoreettisiin lähtökohtiin ja analyysimenetelmiin [Views of research methods II - perspectives for the beginner researcher of the theoretical premises and methods of analysis] (pp. 44-67). Jyväskylä: PS-kustannus.

Moltu, B. (2004). Etnografi og kunnskapsproduksjon. Om å skrive seg ut av feltarbeidet [Ethnography and knowledge production. About to arise out of the field work]. Norsk 
Antropologisk Tidsskrift, 15 (4), 241-256.

Murillo, L. A. (2009). "This great emptiness we are feeling": toward a decolonization of schooling in Simunurwa, Colombia. Anthropology \& Education Quarterly, 40(4), 421-437. doi:10.1111/j.1548-1492.2009.01062.x, http://dx.doi.org/10.1111/j.1548-1492.2009.01062.x

Nystad, I. M. K. (2003). Mannen mellom myte og modernitet [The man between myth and modernity]. Nesbru: Vett \& Viten.

Ogbu, J. (1981). School ethnography: a multilevel approach. $A E Q, 12,3-29$.

Opas, M. (2004). Mitä on uskontoetnografia [What is religion ethnography]? In O. Fingerroos, M. Opas, \& T. Taira (Eds.), Uskonnon paikka [The place for religion] (pp. 153-182). Helsinki: Finnish Literature Society.

Oser, F., Dick, A., \& Paltry, J. (1992). Effective and responsible teaching. San Franciso: Jossey-Bass.

Oskal, N. (2008). The question of methodology in indigenous research. A philosophical exposition. In H. Minde, S. Jentoft, H. Gaski, \& G. Midré (Eds.), Indigenous peoples: self-determination, knowledge, indigeneity (pp. 331-345). Eburon: Delft.

Osterman, K. F., \& Kottkamp, R. B. (1993). Reflective practice for educators: improving schooling through professional development. Newbury: Corwin Press.

Patton, M. Q. (1990). Qualitative evaluation and research methods. Thousand Oaks: Sage.

Pike, K. (1967). Etic and emic standpoints for the description of behavior. In D. C. Hildum (Ed.), Language and thought: an enduring problem in psychology (pp. 32-39). Princeton: D. Van Norstrand Company.

Porsanger, J. (2007). Bassejoga čáhci. Gáldut nuortasámiid eamioskkoldaga birra álgoálbmotmetodologiijaid olis [Holy River. East Sámi traditional sources of faith in relation to indigenous methodology]. Kárášjohka: Davvi girji.

Prior, D. (2007). Decolonising research: a shift toward reconciliation. Nursing Inquiry, 14 (2), 162-168. http://dx.doi.org/10.1111/j.1440-1800.2007.00361.x

Rantala, T. (2005). Oppimisen iloa etsimässä: kokemuksen etnografiaa alkuopetuksessa [Looking for the joy of learning: early experience in teaching ethnography]. (Acta Universitatis Lapponiensis No. 88.) Rovaniemi: University of Lapland.

Rantala, T. (2007). Kokemuksen etnografia - avain koulun arjen tunteisiin [Experience of ethnography - the key everyday emotions at school]. In E. Syrjäläinen, A. Eronen, \& V.-M. Värri (Eds.), Avauksia laadullisen tutkimuksen analyysiin [Views about qualitative research analysis] (pp. 126-158). Tampere: Tampere University Press.

Regalsky, P., \& Laurie, N. (2007). 'The school, whose place is this'? The deep structures of the hidden curriculum in indigenous education in Bolivia. Comparative Education, 43 (2), 231-251. doi: 10.1080/03050060701362482, http://dx.doi.org/10.1080/03050060701362482 
Rønning, W. (2002). Likeverdig skole i praksis. Presentasjon av ei kartlegging [Equal education in practice. Presentation of a survey]. (NF-rapport No. 18.) Bodø: Nordlandsforskning.

Saaranen-Kauppinen, A., \& Puusniekka, A. (2006). Triangulaatio [Triangulation]. In KvaliMOTV - Menetelmäopetuksen tietovaranto [KvaliMOTV - The method of teaching knowledge pool]. Tampere: Database of social sciences. [Online] Available: http://www.fsd.uta.fi/menetelmaopetus/ (August 15, 2010)

Sahlström, F. (2008a). Från lärare till elever, från undervisning till lärande: utvecklingslinjer $i$ svensk, nordisk och internationell klassrumsforskning [From teacher to student, from teaching to learning: trends in Swedish, Nordic and international classroom research]. Stockholm: Vetenskapsrådet.

Sahlström, F. (2008b). Där och då, här och nu : några reflektioner över möjligheterna för samtalsanalytisk lärandeforsking att analysera lärande mellan situationer [There and then, here and now: some reflections on the possibilities for conversation analytic learning scattered to analyze learning situations between]. In M. Enell-Nilsson, \& T. Männikkö (Eds.), Erikoiskielet, käännösteoria ja monikielisyys: Vakki-symposium XXVIII. Vaasa 8. - 9.2.2008 [Special Languages, Translation Theory and Multilingualism: Vakki Symposium XXVIII. Vasa 8 - 9 Feb 2008] (pp. 10-30). Vasa: VasaPublication.

Saikkonen, T.-L., \& Miettinen, S. (2005). Kouluetnografi - missä olet? Tutkijaposition paikantamista koulukontekstissa [School ethnographer - where are you? Locating the researcher position at the school context]. Kasvatus, 36 (4), 307-319.

Salo, U.-M. (1999). Ylös tiedon ja taidon ylämäkeä. Tutkielma koulun maailmoista ja järjestyksistä [Top of knowledge and skill hill. Thesis about worlds of school and order]. (Acta Universitatis Lapponiensis, No. 24.) Rovaniemi: University of Lapland.

Sara, J. I. (1987). Skuvla - lagasbiras Sámi birrasiin [School - immediate vicinity of the Sámi environments]. Oslo: Det Norske Samlaget.

Sarivaara, E. K. (2010). Máttuid giela gáhtten: Stáhtusmeahttun sápmelaččaid sámegiela ealáskahttin Suoma bealde Sámis [Saving the language of our ancestors: Language revitalization of 'Non-status' Sami on the Finnish side of Sápmi]. Sámi diedalaš áigecála, 1, $51-69$.

Schanche, A. (2002). Saami skulls, anthropological race research and the repatriation question in Norway. In C. Fforde, J. Hubert, \& P. Turnbull (Eds.), The dead and their possessions: repatriation in principle, policy and practice (pp. 47-58). London: Routledge.

Schoorman, D., \& Bogotch, I. (2010). What is a critical multicultural researcher? A self-reflective study of the role of the researcher. Education, Citizenship and Social Justice, 5 (3), 249-264. http://dx.doi.org/10.1177/1746197910382257

Seitamo, L. (1991). Psychological development in Arctic cultures. (Acta Universitatis Ouluensis Series E.) Oulu: University of Oulu. 
Singh, M., Kenway, J., \& Apple, M. W. (2005). Globalizing education: perspectives from above and below. In M. W. Apple, J. Kenway, \& M. Singh (Eds.), Globalizing education: policies, pedagogies, \& politics (pp. 1-29). New York: Peter Lang.

Skeggs, B. (1999). Seeing differently: ethnography and explanatory power. Australian Educational Research, 26 (1), 33-53.

Smith, C. (Ed.). (2005). Pohjoismainen saamelaissopimus: 13. marraskuuta 2002 nimitetyn suomalais-norjalais-ruotsalais-saamelaisen asiantuntijatyöryhmän 27. lokakuuta 2005 luovuttama luonnos [Sámi Convention in the Nordic Countries: An outline handed in 27 Oct 2005 by a Finnish-Norwegian-Swedish-Sámi work group established in 13 Nov 2002]. Oslo: Arbeids- og inkluderingsdepartementet.

Smith, L. T. (1999). Decolonizing methodologies: research and indigenous peoples. London: Zed Books.

Smith, L. T. (2005). Building a research agenda for indigenous epistemologies and education. Anthropology \& Education Quarterly, 36 (1), 93-95.

Spindler, G. D. (1997). Why have minority groups in North America been disadvantaged by their schools? In G. D. Spindler (Ed.), Education and cultural process. Anthropological approaches (pp. 96-109). ( $3^{\text {rd }}$ ed.) Prospect Heights: Waveland Press.

Spindler, G., \& Hammond, L. (2000). The use of anthropological methods in education research: two perspectives. Harvard Education Review, 70 (1), 39-48.

Suoranta, J. (1999). Kasvatusantropologia ja (seikkailu)kasvatuksen tutkimus [Educational anthropology and research of (adventure)education]. In J. Suoranta (Ed.), Nuorisotyöstä seikkailukasvatukseen [From juvenile work to adventure education] (pp. 130-170). Tampere: Taju.

Syrjäläinen, E. (1994). Etnografinen opetuksen tutkimus: kouluetnografia [Ethnographic study of education: school ethnography]. In L. Syrjälä, S. Ahonen, E. Syrjäläinen, \& S. Saari (Eds.), Laadullisen tutkimuksen Työtapoja [Qualitative research methods] (pp. 67-112). Helsinki: Kirjayhtymä.

Teddlie, C., \& Tashakkori, A. (2003). Major issues and controversies in the use of mixed methods in the social and behavioral sciences. In A. Tashakkori \& C. Teddlie (Eds.), Handbook of mixed methods in social \& behavioral research (pp. 3-50). Thousand Oaks: Sage.

Tesch, R. (1990). Qualitative research: analysis types and software tools. New York: Falmer.

Trask, H. K. (1993). From a native daughter: Colonialism and sovereignty in Hawai $i$. Monroe: Common Courage Press.

Turner Strong, P. (2005). Recent ethnographic research on North American indigenous peoples. The Annual Review of Anthropology, 34, 253-268. http://dx.doi.org/10.1146/annurev.anthro.34.081804.120446 
Utdanningsdirektoratet. (2007). Gávnos [To be found]. [Online] Available: http://moava.org/files/2011/06/gavnos.pdf (May 29, 2011)

Uusikylä, K. (1980). Miten kuvaan opetustapahtumaa [How do I describe the teaching event]. Helsinki: Gaudeamus.

Valdiviezo, L. (2009). Bilingual intercultural education in indigenous schools: an ethnography of teacher interpretations of government policy. International Journal of Bilingual Education and Bilingualism, 12 (1), 61-79. http://dx.doi.org/10.1080/13670050802149515

Valkonen, S. (2009). Poliittinen saamelaisuus [Political Sáminess]. Tampere: Vastapaino.

Van der Geest, S., \& Finkler, K. (2004). Hospital ethnography: Introduction. Social Science \& Medicine, 59 (10), 1995-2000. http://dx.doi.org/10.1016/j.socscimed.2004.03.004

Vilkuna, J. (2005). Kuka olet maailman ensimmäinen saamenkulttuurin professori? [Who are you, the first professor of Sámi culture in the world?] Kaltio, 5/2005, 258. [Online] Available: http://www.kaltio.fi/index.php?770 (February, 7, 2007)

Vizenor, G. (1999). Manifest manners. Lincoln: University of Nebraska Press.

Wardell, M. (2006) Woolaning: an experiment in indigenous education. Sydney: Macquarie University. [Online] Available: http://www.aare.edu.au/06pap/war06063.pdf (August 15, 2011)

Webster, J. P., \& John, T. A. (2010). Preserving a space for cross-cultural collaborations: an account of insider/outsider issues. Ethnography and Education, 5 (2), 175-191. doi: 10.1080/17457823.2010.493404, http://dx.doi.org/10.1080/17457823.2010.493404

Wolcott, H. F. (1997). The teacher as an enemy. In G. D. Spindler (Ed.), Education and cultural process. Anthropological approaches (pp. 77-92). ( $3^{\text {rd }}$ ed.) Prospect Heights: Waveland Press.

Wulf, C. (2002). Anthropology of education: history and theory of anthropology. Münster: Lit Verlag.

Wulf, C. (2008). Producing the social in rituals. Education and learning, mimesis and performativity. In P. Siljander \& A. Kivelä (Eds.), Kasvatustieteen tila ja tutkimuskäytännöt: paradigmat katosivat, mitä jäljellä? [Status of education and research practices: paradigms disappeared, what is left?] (pp. 51-71). Helsinki: Finnish Educational Research Association.

Øzerk, K. (2006). Opplceringsteori og laereplanforståelse: en laerebok med vekt på kunnskapsløftet, rammeplan for barnehager og aktuelle kunnskaper for pedagoger [Educational theory and curriculum understanding: a textbook with an emphasis on knowledge promotion, curriculum for kindergarten and relevant knowledge for educators]. Vallset: Oplandske Bokforlag.

Young, L. M. (2010). An Indigenous education model for post-secondary academic writing instruction. Fairbanks: University of Fairbanks. [Online] Available: 


\section{Macrothink}

Journal of Studies in Education ISSN 2162-6952

http://ankn.uaf.edu/Curriculum/Masters_Projects/LetaYoung/FinalProject.pdf (August 30, 2011)

Zahorik, J. A. (1975). The effect of planning on teaching. The Elementary School Journal, 71, 143-151. 